\title{
PENGENALAN GOOGLE MEET SEBAGAI SARANA INFORMASI DI TENGAH PANDEMI COVID-19
}

\author{
Nurwati $^{1^{*} \text {, Wan Mariatul Kifti }}{ }^{2}$, Fauriatun Helmiah ${ }^{3}$ \\ ${ }^{1}$ Prodi Teknik Komputer, STMIK Royal \\ ${ }^{2}$ Prodi Sistem Informasi, STMIK Royal \\ ${ }^{3}$ Prodi Manajemen Informasi, STMIK Royal \\ email:*nurwati763@gmail.com
}

\begin{abstract}
The Dadimulyo Village, West Kisaran District, Asahan Regency, which is located at PD. Indah street No.17 Sei Renggas, Kota Kisaran Barat District has Quality Family Cadres, the problem that occurs to these cadres is that there is still a lack of knowledge about technology that allows them to use information delivery media to information users and vice versa. This is an obstacle due to the pandemic situation Covid 19 is currently requiring everyone to work from home. From the results of the training that we have done to family planning cadres in Dadimulyo Asahan Village, it is felt to be very useful. This is based on the results of the knowledge of the cadres who are enthusiastic in participating in this activity and gain useful experience and knowledge which can then be utilized at the Dadimulyo village office.
\end{abstract}

Keywords: cadre; Covid-19 pandemic; Google Meet.

Abstrak: Desa Dadimulyo kabupaten Asahan yang beralamat dijalan PD. Indah No.17 Sei Renggas memiliki kader keluarga berkualitas, Permasalahan yang terjadi pada para kader tersebut yaitu masih kurangnya ilmu pengetahuan tentang teknologi yang memungkinkan dapat menggunakan media penyampaian informasi kepada pengguna informasi begitupun sebaliknya. Hal ini menjadi sebuah kendala karena situasi pandemi covid-19 saat ini yang mengharuskan semua kalangan bekerja dari rumah. Dari hasil pelatihan yang telah kami lakukan kepada para kader keluarga berkualitas di kelurahan Dadimulyo Asahan dirasakan sangat bermanfaat. Hal ini berdasarkan hasil dari pengetahuan para kader yang antusias dalam mengikuti kegiatan ini dan mendapatkan pengalaman serta ilmu yang bermanfaat kemudian dapat dimanfaatkan di kelurahan Dadimulyo.

Kata kunci: Google Meet; kader; pandemi Covid-19. 
Available online at https://jurnal.stmikroyal.ac.id/index.php/jurdimas

\section{PENDAHULUAN}

Saat ini pandemi Covid 19 merupakan suatu permasalahan global terjadi di seluruh belahan dunia, penyakit ini bisa menular dari satu individu ke invidu lainnya. Cara penularan dapat melalui cairan dari batuk, bersin dan kontak langsung dengan penderita penyakit tersebut. Hal ini menuntut setiap instansi untuk mengambil keputusan agar semua orang tetap tinggal dirumah dan menjaga jarak satu sama lainnya. Sehingga mengakibatkan sebagian aktifitas terhenti karena kondisi tersebut (Juniartini \& Rasna, 2020).

Sejumlah instansi pemerintahan dan sarana pendidikan mulai beradaptasi dengan memberikan tugas atau pekerjaannya yang sebagian dilaksanakan di rumah masing masing (Work From Home) dan untuk para siswa melaksanakan pembelajaran secara online. Beruntungnya saat ini kemajuan teknologi sangat cepat dan sangat membantu dalam berbagai aspek kehidupan manusia. Salah satu aplikasi yang dapat mendukung hal ini adalah Google Meet yaitu aplikasi video conference yang digunakan untuk proses meeting secara online (Rezki, Kholifah, Faisal, Priyono, \& Suryadithia, 2020).

Terdapat beberapa penelitian yang mengkaji mengenai penggunaan aplikasi goole meet, pada penelitian (Pernantah, Nova, \& Ramadhani, 2021) Perbandingan aplikasi paling efektif saat pembelajaran daring menurut siswa $\mathrm{X}$ IPS 1 SMA Negeri 3 Pekanbaru ialah aplikasi Google Meet yakni sekitar 62,5\%, aplikasi Google Classroom 25\%, Whatsapp Group dengan persentase $12,5 \%$ ini menunjukan bahwa pembelajaran online menggunakan Google Meet adalah solusi yang sangat efektif bagi guru untuk menghidupkan kembali proses belajar mengajar selama pandemi Covid-19. Pada penelitian (Pakpahan \& Fitriani, 2020) menyatakan bahwa peranan teknologi informasi sangat membantu dalam proses pembelajaran jarak jauh ditengah pandemi virus corona covid-19 semua proses belajar mengajar bisa tetap dilakukan dengan baik berkat bantuan kemajuan teknologi informasi yang sudah sangat maju saat ini, internet bisa menghubungkan dosen dan mahasiswa melalui laman elearning, whatsapp, google class, aplikasi zoom maupun you tube.

Kelurahan dadimulyo mempunyai kader yang berasal dari masyarakat yang merupakan kader atau tenaga sukarela, hal ini dilakukan sebagai bentuk upaya peningkatan keterpaduan peran serta masyarakat. Makna tenaga sukarela yang dimaksud dalam pengertian kader KB (Keluarga Berkualitas) memang tidak diatur secara tegas. Permasalahan yang terjadi saat ini adalah masih kurangnya ilmu pengetahuan tentang media yang dapat dimanfaatkan untuk penyampaian informasi kepada pengguna informasi begitupun sebaliknya hal ini terjadi karena pada masa pandemi ini mengharuskan kita bekerja dari rumah demi memutus mata rantai virus covid-19, maka dibutuhkan pelatihan bagi para kader agar dapat membantu dan memudahkan pekerjaan mereka.

Berdasarkan permasalahan tersebut, maka tim pengabdian yang merupakan dosen-dosen STMIK Royal bergerak untuk melakukan sosialisasi kepada kader dalam penggunaan aplikasi google meet sebagai sarana informasi di tengah pandemi covid-19. Melalui bantuan aplikasi ini sebagai media informasi guna memudahkan para kader untuk menyampaikan informasi kepada pengguna informasi. 
Sarana merupakan segala sesuatu yang dapat dipakai sebagai alat dalam mencapai maksud dan tujuan; alat; media. sedangkan informasi merupakan data yang diolah menjadi bentuk yang lebih berguna dan lebih berarti bagi yang menerimanya. Informasi sebagai hasil dari pengolahan data dalam suatu bentuk yang lebih berguna dan lebih berarti bagi penerimanya yang menggambarkan suatu kejadian-kejadian yang nyata yang digunakan untuk pengambilan keputusan (Mujiati \& Sukadi, 2016)

\section{METODE}

Kegiatan ini dilaksanakan pada tanggal 19 januari 2021 di aula kantor lurah Dadimulyo dan diikuti sebanyak 20 kader. Kegiatan ini dilaksanakan dengan cara memberikan pelatihan kepada peserta kader keluarga berkualitas, yaitu berupa penyampaian materi tentang informasi kepada kader, kemudian dilanjut dengan penggunaan aplikasi google meet di media informasi dalam hal ini menggunakan laptop masing masing dan juga sesi tanya jawab yang disampaikan oleh kader.

Tim pengabdian menyediakan panduan siangkat untuk melakukan instalasi dan pengoperasian awal Google Meet yang menjadi platform pelatihan kader. Peserta kader juga dapat menghubungi panitia agar dapat dibantu secara teknis dalam melakukan instalasi maupun menjalankan aplikasi ini untuk pertama kalinya. Pada saat hari pelaksanaan dilaksanakan kegiatan pretest kepada peserta mengenai pemahaman peserta mengenai platform yang akan diajarkan pada pelatihan ini. Kegiatan berikutnya adalah pemaparan materi yang dilaksanakan oleh instruktur dan praktek yang diikuti oleh para peserta. Modul materi dikirimkan kepada masing-masing peserta kader sehingga diharapkan peserta dapat mengikuti materi yang disampaikan. Kegiatan pelatihan ini diakhiri dengan kegiatan post-test peserta. Seluruh proses kegiatan pelatihan ditutup dengan kegiatan evaluasi kegiatan. Evaluasi ini dilaksanakan secara online dan dihadiri oleh seluruh anggota panitia pelaksana. Pada evaluasi ini dijabarkan mengenai hasil post-test dan timbal balik peserta mengenai kegiatan pelatihan ini. Di samping itu, juga disampaikan kritik dan saran mengenai teknis pelaksanaan pelatihan ini.

\section{PEMBAHASAN}

Sesuai dengan rencana pelaksanaan pengabdian masyarakat mengenai tema "Pengenalan Google Meet sebagai sarana Informasi di Tengah Pandemi Covid 19" ,maka kegiatan tersebut telah direalisasikan sesuai dengan rencana dan berjalan dengan lancar.Banyaknya dukungan dari berbagai pihak baik dari pihak kampus STMIK Royal melalui Lembaga Penelitian dan Pengabdian Masyarakat dan juga pihak kelurahan dadimulyo.

Dari hasil pelatihan yang telah kami lakukan kepada para kader dirasakan sangat bermanfaat. Hal ini berdasarkan hasil dari pengetahuan kader yang antusias dalam mengikuti kegiatan ini dan mendapatkan pengalaman serta ilmu yang bermanfaat kemudian dapat dimanfaatkan di kelurahan dadimulyo .

Materi pengabdian kepada masyarakat disusun sesuai dengan tujuan yang ingin dicapai diantaranya "Pengenalan Google Meet sebagai Sarana Informasi di Tengah Pandemi Covid 19 ". 
Available online at https://jurnal.stmikroyal.ac.id/index.php/jurdimas

\begin{abstract}
Adapun tahapannya adalah sebagai berikut:

a. Memberikan materi modul kepada seluruh peserta kegiatan Pengabdian kepada Masyarakat

b. Narasumber menjelaskan apa itu Google Meet, fasilitas apa saja yang terdapat pada google meet beserta keunggulan aplikasi tersebut dari google meet itu sendiri.

c. Kemudian para peserta yaitu para kader memahami cara peng-gunaan google meet maka selama pandemic covid-19 dapat di-lakukan Work From Home.
\end{abstract}

Materi dari kegiatan adalah sebagai berikut:

a. Aplikasi google yang sudah terinstal di laptop

b. Masuk ke dalam Google.com

c. Kemudian search meet lalu klik aplikasi google meet

d. Setelah itu klik start a meeting, dan akan muncul Id Google Meet. Id Google Meet digunakan supaya dapat bergabung ke dalam video conference.

e. Tekan Presenting untuk presentasi

f. Kemudian peserta mendapatkan Id Google Meet dan akan meminta untuk bergabung ke dalam video conference dengan tampilan aplikasi google meet "Asking to Joint".

g. Setelah itu menampilkan semua peserta yang terkoneksi dan klik di ujung kanan bawah tanda titik-titik pilih "Change Layout" (Sawitri, 2020).

Berikut adalah tampilan awal Google meet, dapat dilihat pada gambar 1.

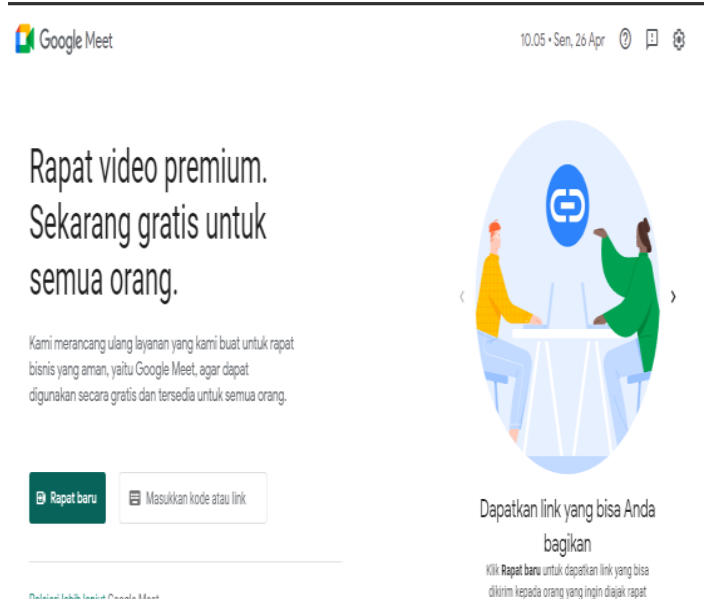

\section{Gambar 1. Tampilan Klik Start a} Meeting

Tampilan para peserta google meet dapat dilihat pada gambar 2 .

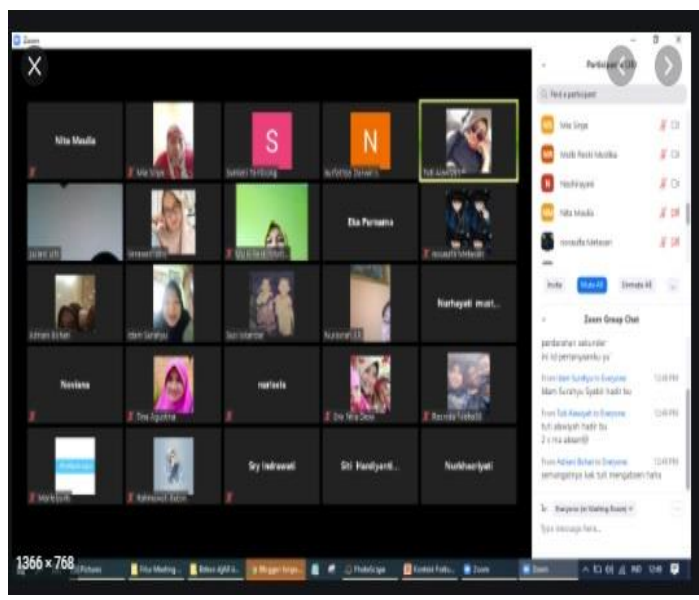

\section{Gambar 2.Tampilan Para Peserta} Google Meet

Hasil yang didapatkan yaitu Para kader di kelurahan dadimulyo dapat menerapkan aplikasi google meet untuk meningkatkan ilmu pengetahuan dan sumberdaya manusia yang berbasis IT. Kemudian dapat membantu dan memudahkan para kader dalam hal memberikan dan mendapatkan informasi walaupun dirumah saja. 


\section{SIMPULAN}

Setelah dilakukan pembekalan dan pelatihan kader kelurahan tentang penggunaan aplikasi google meet sebagai media sarana informasi yang dapat mempermudah pekerjaan para kader dalam hal penyebaran informasi ke berbagai masyarakat/pengguna informasi tanpa harus berkumpul di lingkungan/kantor keluranan. para kader yang berada di lingkungan kelurahan Dadimulyo mendapatkan ilmu yang bermanfaat untuk diterapkan dalam masa pendami Covid19.

\section{DAFTAR PUSTAKA}

Deharja, A., Farlinda, S., \& Santi, M. W. (2019). Peningkatan kompetensi kader dalam pembuatan laporan posyandu berbasis teknologi informasi. Prosiding.

Deharja, A., \& Permatasari, V. (2016). Peningkatan Pengetahuan dan Kreatifitas Kader Melalui Pemanfaatan Teknologi SMS Gateway Untuk Mengoptimalkan Kunjungan Posyandu. Prosiding.

Gustiana, G. (2021). Training using google meet for elementary school teachers. Jurnal pajar (Pendidikan dan Pengajaran), 5(3).

Juniartini, N. M. E., \& Rasna, I. W. (2020). Pemanfaatan Aplikasi Google Meet Dalam Keterampilan Menyimak Dan Berbicara Untuk Pembelajaran Bahasa Pada Masa Pandemi Covid-19 1Nme. Jurnal Pendidikan Dan Pembelajaran Bahasa Indonesia, 9(2), 133-141.

Mujiati, H., \& Sukadi. (2016). Analisis Dan Perancangan Sistem
Informasi Stok Obat Pada Apotek Arjowinangun. Indonesian Jurnal on Computer Science, 9330(2), 16.

Nalurita, S. (2020). Pemanfaatan Aplikasi Google Meet Pada Mata Kuliah Teknik Proyeksi Bisnis Semester Gasal Tahun Pelajaran 2020/2021 Di Universitas Dirgantara Marsekal Suryadarma (Unsurya)(Studi Pada Mahasiswa Prodi Manajemen Kelas G). Jurnal Ilmiah Manajemen Surya Pasca Scientia, 10(1).

Octafian, D. T., Putri, M. P., \& Andriani, E. (2021). Penggunaan Aplikasi Google Meet Sebagai Pendukung Kegiatan Mengajar Saat Menghadapi Pandemi Covid-19 Bagi Guru SD N 149 Palembang. Jurnal Karya Abdi Masyarakat, 5(1), 154-160.

Pakpahan, R., \& Fitriani, Y. (2020). Analisa Pemafaatan Teknologi Informasi Dalam Pemeblajaran Jarak Jauh Di Tengah Pandemi Virus Corona Covid-19. JISAMAR (Journal of Information System, Applied, Management, Accounting and Researh), 4(2), 30-36.

Pernantah, P. S., Nova, N., \& Ramadhani, A. S. (2021). Penggunaan Aplikasi Google Meet dalam Menunjang Keefektifan Belajar Daring Masa Pandemi Covid-19 di SMA Negeri 3 Pekanbaru. Pedagogi: Jurnal Ilmu Pendidikan, 21(1), 45-50. doi: 10.24036/pedagogi.v21i1.991

Rezki, M., Kholifah, D. N., Faisal, M., Priyono, P., \& Suryadithia, R. (2020). Analisis Review Pengguna Google Meet dan Zoom Cloud Meeting Menggunakan 
Jurdimas (Jurnal Pengabdian Kepada Masyarakat) Royal

Vol. 4 No. 3, September 2021, hlm. 287 - 292

ISSN 2614-7912 (Print)

DOI: https://doi.org/10.33330/jurdimas.v4i3.1169

ISSN 2622-3813 (Online)

Available online at https://jurnal.stmikroyal.ac.id/index.php/jurdimas

Algoritma Naïve Bayes. Jurnal Infortech, 2(2), 264-270. doi: 10.31294/infortech.v2i2.9286

Sari, S. F., \& Puspita, Y. Optimalisasi Media Digital Sebagai Sarana Penyampaian Informasi di Tengah Pandemi Covid-19. Jurnal Pengabdian Masyarakat PGSD,
1(1), 32-45.

Sawitri, D. (2020). Penggunaan Google Meet Untuk Work From Home Di Era Pandemi Coronavirus Disease 2019 ( Covid-19 ). Jurnal Pengabdian Masyarakat, 